\section{Impact of the Digital Didactic Material on Students' Reading and Grammar Acquisition}

DOI: https://doi.org/10.17345/ute.2020.1

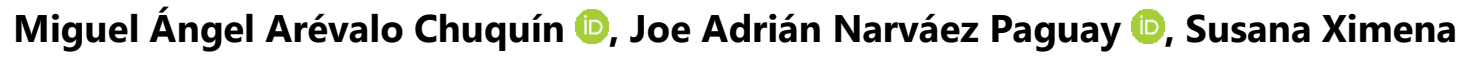 \\ Orellana Mora
}

Rebut: 02/7/2019 Acceptat: 09/10/2019

\begin{abstract}
The present study utilized Digital Didactic Material, namely: Grammarly, Kahoot!, LyricsTraining, Qr Codes, Quizalize, Quizizz, Quizlet, and Storybird to teach EFL (English as a Foreign Language) namely reading comprehension and grammar formation. This study also aimed at investigating the learners' acceptance toward this material. To evaluate the effectiveness of the proposed approach, 37 university students of two general English language courses attending classes in the Language Institute at the University of Cuenca, Ecuador, participated in a pre-experimental design. The experimental results indicated that students' reading and grammar acquisition outperformed significatively after employing the Digital Didactic Material $(p<.05)$. Moreover, students showed a positive attitude to this material as well as its use in teaching reading comprehension and grammar structure. The findings of this study have implications for L2 learners, encouraging them to change their view of reading and grammar acquisition and looking at these from a more motivating perspective.
\end{abstract}

Keywords: Digital Didactic Material, EFL, grammar, reading, technology

\title{
Resumen
}

El presente estudio utilizó Material Didáctico Digital, a saber: Grammarly, Kahoot!, LyricsTraining, códigos Qr, Quizalize, Quizizz, Quizlet y Storybird para enseñar EFL (English as a Foreign Language); es decir, comprensión lectora y la formación de la gramática. Este estudio también tuvo como objetivo investigar la aceptación de los estudiantes hacia este material. Para evaluar la efectividad del enfoque propuesto, 37 estudiantes universitarios de dos cursos de inglés general participantes en las clases del Instituto de Lenguas de la Universidad de Cuenca, Ecuador, quienes fueron parte de un diseño preexperimental. Los resultados experimentales indicaron que la lectura de los estudiantes y la adquisición de la gramática superaron significativamente después de emplear el Material Didáctico Digital (p. 05). Además, los estudiantes mostraron una actitud positiva hacia este material; así como su uso en la enseñanza de la comprensión lectora y la estructura de la gramática. Los hallazgos de este estudio tienen implicaciones para los estudiantes de una segunda lengua, alentándolos a cambiar su visión de la lectura y la adquisición de la gramática y observándolos desde una perspectiva más motivadora.

Paraules clau: Material Didáctico Digital, EFL, gramática, lectura, tecnología. 


\section{Background to the study}

One of the characteristics of using elements such as Digital Didactic Materials in a foreign language learning classroom links directly to motivation in learning. Intrinsic motivation can be considered as the main factor for engagement (Zarzycka-Piskorz, 2016). Researchers state that the use of didactic material must be according to the way the students learn nowadays (Almirón \& Porro, 2014). It is because of this aspect that digital-oriented approaches have been chosen in order to have a clear insight of how these influence in an environment such as the University of Cuenca, in Ecuador. Intensive level students who take English courses tend to have issues related to a misuse of English in its various forms because of factors like extended time when coming back to study the language again, age gaps in relation to other classmates, somewhat difficult schedules, among others.

\section{Technology in the classroom and digital didactic material}

In recent years, virtual activities have gained great importance since they are considered as a means of motivation through which individual and group work is improved. Also, it has been proven that they enhance knowledge comprehension and scientific reasoning (Fiad \& Galarza, 2015). As added by Ruiz (2011), educators have to change their traditional ways into new ones, since the new generation of students are constantly challenging the learning process.

The importance of having technology to support learning in a classroom, according to students' demands is already there, but as educators there is a challenging scheme in which instruction must become enhanced in search for academic betterment and maintaining students' integrity (Courts \& Tucker, 2012). As these authors mention, the expectations coming from "technologically savvy students towards an updated classroom atmosphere which meets their capabilities become higher by each year, so there is the intrinsicate need of implementing a more dynamic curriculum" (p. 122).

Akdemir et al. (2012) state that technological aids have the capacity of presenting immediate feedback for teachers and students, with the reinforcement of mental and physical participation during class time. These aids allow educators to improve the quality of education, through the improvement of the exchange between students and teachers, and between them and technology (Ortega \& Medina, 2015). The online aids used in the present study have the characteristic of approaching meaningful and memorable learning for the participants through collaboration and participation in a competitive class environment. It allows the language teaching community to acquire a clear insight of technological ways and their outcomes in a short period of time.

Computer Assisted Language Learning for reading has certain features which allow students in proximity, to be fully engaged with their own individual devices, and it is possible to create more collaborative and partaking learning experiences as Hsu et al. (2013) mention.

Among studies that can show the effectiveness of technology integration into the English curriculum are the following: Zarzycka-Piskorz (2016) who integrated Kahoot! In order to observe and assess how the students' motivation increased to learn and practice grammar, and how effective this model of learning was. She observed 112 university students. Their English level was upper-intermediate. The findings regarding to the question: "Does Kahoot! game motivate you to learn grammar?" showed that $70 \%$ of students felt motivated to learn grammar after they played Kahoot!; in contrast, $26 \%$ of the participants seemed rather indifferent. In summary, three out of four students were fairly strongly driven to take in the grammatical content. 
On a more familiar context, Cabrera et al. (2018) conducted a study that examined the use of Pixton for enhancing grammar and vocabulary teaching at a public high school in the southern region of Ecuador. In this intervention, 163 junior high school learners participated during a period of 4 months. After analyzing the data quantitatively and qualitatively, the results indicated that Pixton accounts as an effective teaching tool that motivates students to learn grammar and vocabulary in an enjoyable way; this was evident through an improvement in students' posttest scores of 3.9294 points in the experimental group.

A quasi-experimental, pre/posttest design study was carried out in Jordania by Bataineh and Mayyas (2017) and used Moodle in language teaching at a Jordanian state university. In this study, a sample of 32 students enrolled in a language requirement course was randomly divided into an experimental group $(n=17)$ and a control group $(n=15)$. The former group used blended learning in which the Moodle platform was employed together with in-class instruction, whereas the latter used in-class instruction only. The results of the posttest indicated that the experimental group outperformed the control group (at $\alpha=0.05$ ) in both reading comprehension and grammar.

On the reading comprehension aspect, the findings that researchers like Slavin et al. (2009) have encountered suggest that there is potential for technology to improve reading outcomes. The authors state that technology can maximize student engagement by providing them with metacognitive strategies for text comprehension, as well as strengthening other skills. Also, besides being a great support in the learning process, technology promotes creativity, and technological and cultural advancements; thus, leading to the development of a society of knowledge (Chávez \& Caicedo, 2014).

Moreover, some other authors claim that adding new methodologies like virtual laboratories, smartphones, the use of digital didactic material and others, generates significant learning outcomes in students who are nowadays surrounded by technological devices (Ausín et al., 2016; Bravo et al., 2016; Faúndez et al., 2015). Computer-based learning environment promotes a setting in which students are involved into theory and practice at the same time, which evolves into an effective and active learning process (Crujeiros \& Jiménez, 2015).

\section{Reading comprehension: reading for detail}

Increased access to the invention of reading represented increased individual access to cultural knowledge and associated power as Johnson (2015) mentions. This author accurately states that reading and writing are two distinct processes, but the invention of a system of written symbols was a prerequisite to the invention of reading.

With this background information, it is considered that the skill of reading is referred as the process of deriving meaning from symbolic representations (Johnson, 2015). This author states that English text derives meaning from 26 symbols (alphabet) presented with seemingly infinite combinations (sentences and paragraphs), 14 printed symbols (punctuation) and text conventions as well as indentations and space between texts.

Gilmanova et al. (2016) classify the types of reading based on its purpose and organization, having skimming (reading for gist), which requires a general understanding of the text, learning its principal points in order to summarize the text mostly for obtaining a general idea of it. In contrast, scanning (reading for specific information) is used specifically for obtaining specific information about the text to know if it contains necessary information, which better leads to detailed reading (reading for comprehension) which has its importance on complete and thorough details and facts in order for a learner to evaluate, comment or clarify a text's features. By learning how to use these subskills and 
comprehending texts, learners are expected to obtain an array of information and knowledge which later on will compensate them in developing language competences as well as language performances. But it is important to mention that those given texts are not $100 \%$ hard copy texts. Most of those texts are nowadays presented digitally because of their availability since "the individual ability to read and access text are currently considered fundamental to personal and social progress" (Organization for Economic Cooperation and Development, 2013, p. 109).

The improvement of reading skills relies in part on customizing reading materials to individual students by considering their profiles and learning styles as Liu Liu and Hwang (2011) point out. The need for quality readers is imperative to better systematize and improve learning systems.

\section{Grammar: sentence structure}

As defined by Turkmen and Ayden (2016), grammar is the basics of the English language, which allows ESL learners to read, write, speak and understand English effectively. According to these authors, grammar does not necessarily rely on the pre-existence of language, so it is possible for some elements of grammar to be prototyped as features of other mental features before language appeared. From its early beginnings, grammar has encompassed significant events that indicate change in human survival strategies, for which many left record of intellectual achievement.

Looking at its development more recently, from the seventeenth century, the process of teaching grammar has evolved (Althaqafi, 2018). This process started with the Translation Method (The Classical Method) to the Task-Based Learning (TBL)/ or Task-Based Instruction (TBI). The first implies a very structured way of teaching grammar through translation to and from the mother tongue (Polat, 2017). The latter means the use of context and meaningful tasks (Ellis, 2017). However, both and others are important in the teaching of grammar and depending on the purpose of the study, teachers can use them in a recycling way, by analyzing grammar in parts or as a whole. Grammatical range and accuracy as well as appropriate use of this resource are exponents which convey in the use of a foreign language.

Additionally, Larsen-Freeman (2015) has led "a futile campaign to convince others that grammar actually has to do not only with form and meaning, but also with use in texts..." (p. 272). Two examples to picture his intention are the use of phrasal verbs instead their single verbs with the same meaning and the use of a specific verb tense.

The present study had two objectives. The first one was to determine the impact of Digital Didactic Material on students' reading comprehension. The second one was to establish the impact of Digital Didactic Material on students' grammar acquisition. Pertinent to the first objective, a hypothesis to know if there was some statistically significant improvement in reading comprehension by means of the use of Digital Didactic Material was outlined. A similar hypothesis to prove the second objective was to acknowledge if there was any statistically significant improvement in grammar formation throughout the use of Digital Didactic Material. 


\section{Methodology}

\subsection{Settings and participants}

The methodology addressed the quantitative and qualitative methods used for data collection and analysis. It was a pre-experimental design, also grounded as empirical and interventional which also looked to estimate its impact on a group of people to determine the effect of digital resources like specifically adapted IRS material (independent variable) on students' reading comprehension and grammar structure subskills (dependent variables). Hence, it allowed the researcher to control the treatment practice.

This study was conducted in a public university in the southern region of Ecuador, and there were 37 participants in this case study: 29 women and 8 men, all of them native Spanish speakers. The participants' age average was 24 , but it is important to mention that there was one participant who was 18 and one who was 57 by the time the study took place. $80 \%$ of them were only students and $20 \%$ were people who had different occupations like being a chef or a teacher. $90 \%$ of the students only studied English and from these students $40 \%$ had a major and were currently coursing it (Medicine, Basic Education, and Communication mainly). Only $10 \%$ of the students studied another language: French.

They were in their 4th level of two intensive courses of English offered by the Institute of Languages of the University of Cuenca. According to the Common European Framework of Reference for Languages, 4th level constitutes a level A2 of English (Council of Europe, 2001). Also, three university English tutors participated in this study in order to validate the instruments used for collecting data. Due to ethical concerns participants received a copy of the consent form in order to participate in the study.

The intensive level students from the current study were people from different majors, universities or even people who were not currently studying any other subject rather than English. Each class normally admitted no more than 25 students, and the class periods lasted 120 minutes.

These intensive course students had a workload of 10 hours per week (adding a total of 70 hours in two months); the age expected was between 19-30 years old. Their mother tongue was Spanish, and the gender was distributed randomly.

For this study, participants were required to visit a computing lab every week for two hours; time in which the researcher applied Digital Didactic Material to address reading comprehension and sentence formation.

\subsection{Research design}

The present study was framed within pre-experimental designs (pretest / posttest) with a single group (Hernández et al., 2010), but also, it included an open explanation about why students chose an answer in a survey of opinion, in which case, the design used was also of concurrent triangulation (Creswell, 2014).

\subsection{Instruments used for fostering reading and grammar skills}

The tools used with students in their English learning process account as Interactive Response Systems, which are used for raising student awareness and increasing their classroom involvement and participation (Stowell \& Nelson, 2007). Within the present study, there were seven didactic tools which were selected from online sources and the characteristic they have of helping students focused on comprehension rather than input only (Dangel \& Wang, 2008). Table 1 provides a list of the seven tools that were applied with students during their English classes, their definitions, uses and activities. 
Table 01:Digital Didactic Material applied with their definitions, uses and activities in the present study.

\begin{tabular}{lll}
\hline $\begin{array}{c}\text { Digital Didactic } \\
\text { Material }\end{array}$ & Definition and Use & Activities
\end{tabular}

\begin{tabular}{lll}
\hline Grammarly & An application that automatically detects & Write sentences and paragraphs to create a story using \\
potential grammar, spelling, punctuation, word & Storybird. Use Grammarly in order to check grammar \\
choice, and style mistakes in writing. & formation and correct your mistakes.
\end{tabular}

Kahoot

A tool with ready quizzes to be used for practicing acquired knowledge.

LyricsTraining

Qr Codes

Quizalize

Quizizz

Quizlet

Storybird assessments

\begin{abstract}
A website with music videos and their lyrics where you need to fill the gaps with the correct word in order to continue listening the song selected.

Codes that can direct you to a webpage, video, or file in an easier way than type them.
\end{abstract}

An online platform for classroom polling and assessing that can be access by computer, tablet or mobile phone.

A website to conduct students' formative

A game-based platform that can be played in real time with flashcards, games, and other tools to help fostering student creativity.

A language arts tool with illustrations that help members to write stories.
Practice the grammar structures learned in class by using Kahoot live game. Individually, answer the questions Kahoot presents you on the board by using your computers.

Fill in the blanks. Work in pairs. You have 10 minutes to complete them.

Read the story in the different five stages. You have 10 minutes to read it.

Practice the grammar structures studied in class by means of interactive quizzes.

Practice the grammar structures studied in class by using Quizizz activities like: matching cards, play and learn, among others. Play in groups of 3 in order to finish the activities presented in Quizizz Live.

Practice the grammar structures studied in class by using Quizlet activities like: live, matching cards, learn, and so on. Play in groups in order to finish the activities presented in Quizlet Live.

Write a story (250 words). Then, read your classmates' stories and comment on them. 


\subsection{Procedure}

The data for this study were gathered for a period of eight weeks in the academic period of November 2018-January 2019, which was the extent of an intensive course at the Language Institute of the University of Cuenca.

The group of students for this research was aimlessly assigned to the instructor by the Intensive English program of the University of Cuenca. The participants were taught reading and grammar by means of a textbook. In addition, supplementary materials were prepared for the group according to the pensum of study of the institute in which they study. These activities were digitally designed. Table 2 shows the description of tasks designed for the participants.

Table 02: Description of Task Design

\begin{tabular}{|c|c|c|}
\hline Skill & Tasks & Digital Tools \\
\hline Reading & Overall Reading Comprehension & $\begin{array}{l}\text { LyricsTraining } \\
\text { Qr Codes } \\
\text { Storybird }\end{array}$ \\
\hline Grammar & Sentence formation & $\begin{array}{l}\text { Grammarly } \\
\text { Kahoot! } \\
\text { Quizlet } \\
\text { Quizizz } \\
\text { Quizalize }\end{array}$ \\
\hline
\end{tabular}

Table 02 provides a description of the two skills in which the study was focused, as well as the tasks and the specific digital tools that were used during the methodology.

The intervention with the treatment groups consisted of the use of digital material on a weekly basis during class time by using the computer lab with individual access to the CPUs. This was done in order to carry out the previously designed interactive tasks to practice reading and grammar structures from the syllabus' contents. There was also the possibility of using digital material with the aid of cellphones to work collaboratively within the class. The design of the digital material tasks took approximately a month starting from October 1st to November 1 $1^{\text {st }}, 2018$.

This case study included online pre and posttests (previously validated by three experts on ESL teaching), task treatment, computers, Internet, MacMillan's Skillful Foundation textbook, notebooks and Moodle, which is the platform used by the Language Institute of the University of Cuenca. Reading and grammar pre/posttests were designed according to what the students were supposed to learn and handle at their level. Five units of the English book were taken into consideration for this study. The Skillful Foundation book, first edition, by Macmillan, is a book designed for A2 EFL students. The five units for this study were Unit 1: Speed (Comparisons), Unit 2: Vision (Affixes), Unit 3: Extremes (Can), Unit 4: Life (Simple Past) and Unit 5: Plans (Simple Future).

The content taught on two fourth level intensive courses at the Language Institute is based on the Common European Framework of Reference for Languages and its overall A2+ level production. According to the Council of Europe (2001), an A2+ learner is expected to read and comprehend texts with frequent language use, composed of different topics of general, personal and academic interest. Throughout the application of the methodology, the instructor used digital material associated with the specified level content. The researcher was also in the advantage of using the computer lab facilities that the same institution provides, in order to keep track of the individual work of the students with each session. Before conducting the study, the instructor designed each activity guided by the expected 
outcomes of the specified A2+ level which met the topics of the syllabus designed by the Language Institute of the University of Cuenca for students on level 4. The instructor also designed the pre and posttests that evaluated the results of the present study. These tests were two: the first was presented as a short story created by the author on the Storybird platform in consideration of the level's needs for measuring reading comprehension; the other test was designed in aims of averaging grammar structures; multiple choice questions, true-false selection, and word-definition matching were employed. These pre and posttests were taken with a digital input via Moodle. Additionally, students answered a survey of opinion about the use of Digital Didactic Material, in order to know to what extent, they liked the different tools.

The computing laboratory used had all the services needed for the study. It had Internet access, 30 Intel 5 computers for personalized usage and suitable environment for learning. In fact, it had big windows and enough space for students to move around the class. One class completely used the digital material (100\%) and the other class used it partially (60\%).

\section{Analysis}

The sample of 37 students had probability characteristics for the t-test such as the comparison of means of the same group with Wilcoxon Test (matched pairs). Two tails were programmed, a normal distribution, an Effect size $\mathrm{dz}$ of 0.5 , an $\alpha$ probability error or statistical significance of 0.05 , a sample power (1- $\beta$ err prob) of 0.84 . The expected results to verify the hypothesis with 37 cases had a critical value of $t$-test of 2.03 ( $36 \mathrm{df}$ ). The output was obtained with the $\mathrm{G}$ * Power 3.1. sample calculator. (Faul et al., 2007).

The results were processed in the SPSS 24 program. A descriptive statistic was generated with frequencies ( $n$ ) and percentages (\%) for the student's opinion instrument. In the students' score results, means $(\cdot)$, standard deviations (Stand. Dev.) as well as medians (Md.) were calculated. For grammar and reading scores variables, formulated hypotheses were also executed. To verify the hypotheses, the parametric t-test (Field, 2019) was used. Additionally, a qualitative analysis was carried out regarding the tool that students who used Digital Didactic Material liked the most during the course; the software that allowed to organize three codes belonging to the same family was Atlas ti 7 (Muñoz-Justicia \& SahagúnPadilla, 2017).

\section{Results}

\subsection{Students' Score Results}

A t-test for matched pairs was conducted to examine the differences between the pre-evaluation and the post-evaluation of the grammar variable (Table 3). Previously, the assumptions of normality and independence of the difference between the scores of the post-evaluation and the pre-evaluation were checked. Statistically significant differences were found with higher score in the post-assessment (Mean $=6.71$ points, Stand. Dev. $=2.51$ ) than in the pre-evaluation (Mean $=5.45$ points, Stand. Dev. $=1.93)$, $[\mathrm{t}$ $(36 \mathrm{df})=-2.276, \mathrm{p}=014 \mathrm{]}$. The difference between the two means is 1.26 points (Est. Dev. $=2.97$ ), with a confidence interval of $95 \%$ difference of -2.25 and -0.28 . The Cohen's $d$ statistic $(0.55)$ shows a medium effect size (Sawilowsky, 2009).

To analyze the differences between the pre-evaluation and the post-evaluation of the reading variable (Table 3), another $t$ test was conducted. This test was used because the assumption of normality between the difference of the scores of the post-assessment and the pre-evaluation was confirmed. The preevaluation obtained was higher (Mean $=5.57$ points, Stand. Dev. 1.63) than the post-assessment (Mean $=7.36$ points, Stand. Dev. 2.34). The Mean of the differences was 1.80 points (Stand. Dev. 2.75), a 
difference that is considered significant [t (36df) $=-3.976, p=000]$. The Cohen's $d$ statistic $(0.87)$ showed a large effect size (Sawilowsky, 2009).

Table 03: Average of the pre and post evaluation and difference between the two values.

\begin{tabular}{|c|c|c|c|c|c|c|c|}
\hline & \multicolumn{2}{|c|}{ Pretest } & \multicolumn{2}{|c|}{ Posttest } & \multicolumn{2}{|c|}{ Difference } & \multirow[t]{2}{*}{$\mathbf{p}$} \\
\hline & Mean & Stand. Dev. & Mean & Stand. Dev. & Mean & Stand. Dev. & \\
\hline Grammar & 5.36 & 2.37 & 8.96 & 0.55 & 3.60 & 2.41 & 0.000 \\
\hline Reading & 5.06 & 1.56 & 9.29 & 0.85 & 4.24 & 1.68 & 0.000 \\
\hline
\end{tabular}

The minimum value in pretest is 0 and 2 and the maximum is 7 and 8 for the pretest, respectively; and, the minimum value is 9 and 8 and 10 for the posttest respectively. The difference was obtained subtracting the post from the pretest.

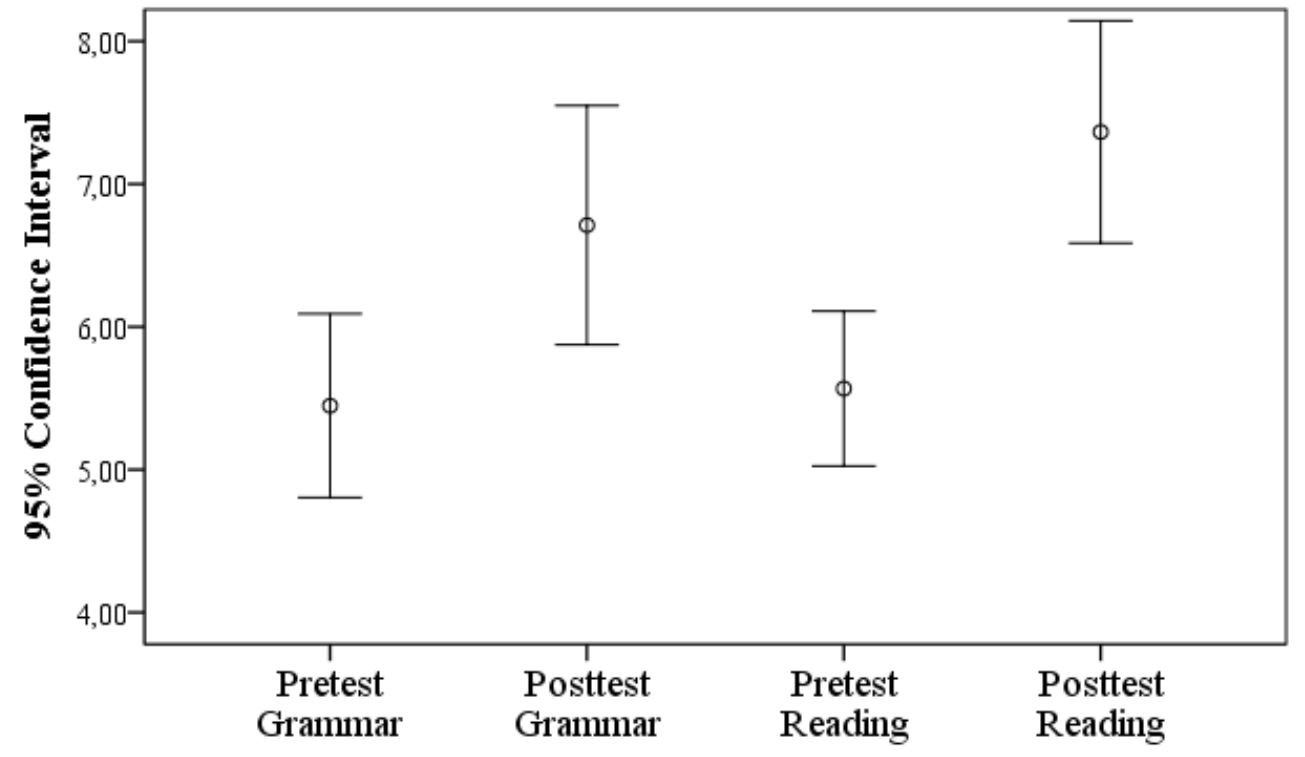

Figure 01. Error bar diagram of the pre and posttests for scores over 10

Figure 1 visually shows an error bar diagram with a confidence interval of $95 \%$ of the students' progress in pre-intervention (pretest) and post-intervention (posttest) situations. In fact, the results leave sees that there is a greater concentration of data in the final situation (all around 7 points) than in the initial situation (which are around 5 and 6 points).

According to the results, it was important to know the anonymous students' opinions about their learning process using a Google Form survey. To the question of which tool was more effective in 
students' English learning process? They answered that the best tool was Quizlet (58.8\%); another important answer was Storybird (35.3\%), almost no one considered Grammarly as the best tool. In fact, the questionnaire includes another question related to their future plans in leaning or practices English. The students included Quizlet and Storybird (more than 70\%) as a tool to use outside of the English course. Another question was: which tool caused more problem or difficulties when you used it? Most of the students $(70.5 \%)$ answered that none of them caused problems. Related to the question, would you recommend teachers and/or students to use these kinds of tools in the English learning process? All the students answered affirmatively. Finally, all the students, except one, considered that their learning process during the last course helped them to improve their grammar abilities.

\subsection{Students' Opinions about the Course}

Simultaneously, the students explained their answers to the open question why? We analyzed the answer using Atlas ti 7. Most of the answers ratified the quantitative answers. In Figure 2, we expose the codes around the central question related to the reasons why the students preferred each tool. The two tools that had more frequency are associated; however, both of them are part of the aim that is grammar.

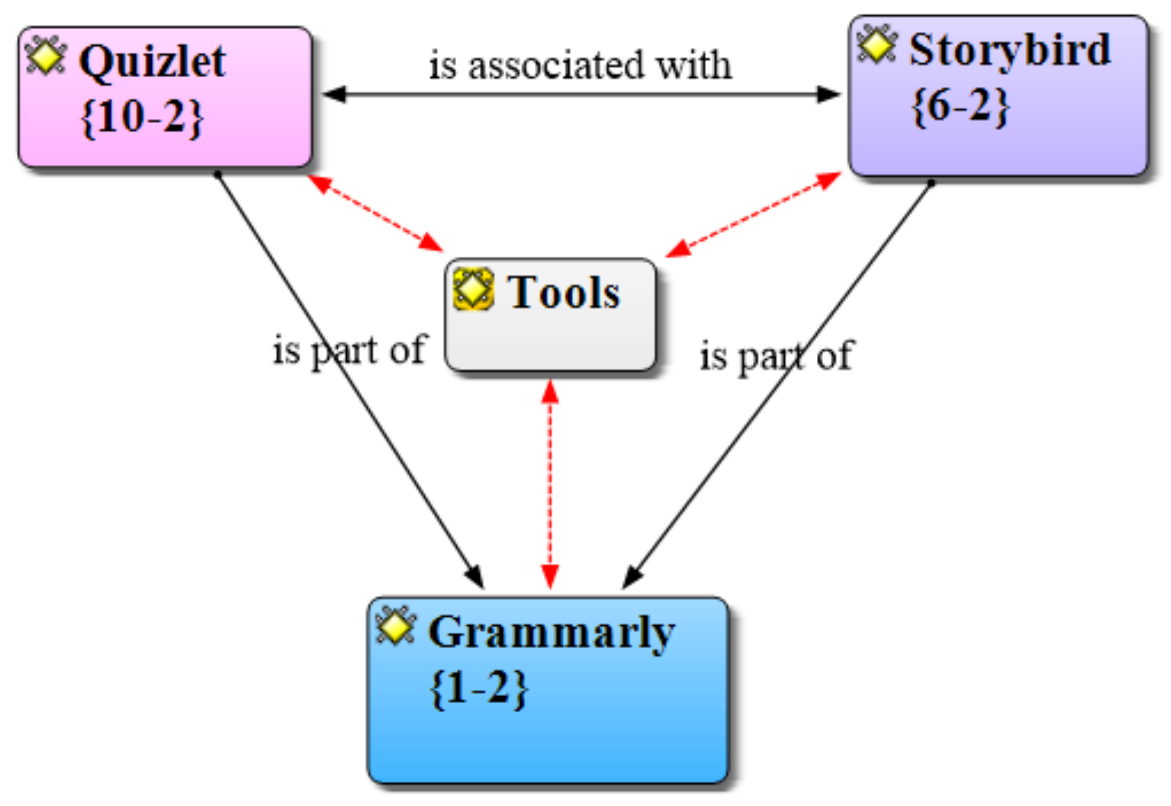

Figure 01- Code families

Figure 02 reveals students' preferences regarding Quizlet and Storybird. For example, two students that chose Quizlet said that this tool helped them with grammar. A similar result showed other two students favoring Storybird; other similar results are related to the development of imagination creating stories, or that the course was dynamic. 


\begin{tabular}{|c|c|c|}
\hline Quizlet $\{10-2\}$ & Storybird $\{6-2\}$ & Grammarly $\{1-2\}$ \\
\hline \multicolumn{3}{|l|}{$\begin{array}{l}\text { "...it helps me with its repetitive form to } \\
\text { learn better" }\end{array}$} \\
\hline "...help me with the grammar" & $\begin{array}{l}\text { "...we put our grammar into practice and } \\
\text { also our imagination" }\end{array}$ & \\
\hline $\begin{array}{l}\text { "...allows us to learn grammar with } \\
\text { individual and groups games" }\end{array}$ & "...practice my grammar" & \\
\hline $\begin{array}{l}\text { "...lot of option and activities where you can } \\
\text { practice" }\end{array}$ & "...improvise and practice the pronunciation" & \\
\hline $\begin{array}{l}\text { "...write a story and expose to our } \\
\text { classmates" }\end{array}$ & "It helped us to developing our imagination" & \\
\hline "...more dynamic" & $\begin{array}{l}\text { "The teacher methodology was amazing, } \\
\text { fun..." }\end{array}$ & \\
\hline \multicolumn{3}{|l|}{ "It facilitates the learning and practice" } \\
\hline \multicolumn{3}{|l|}{$\begin{array}{l}\text { "...because I work in a group and based on } \\
\text { pressure" }\end{array}$} \\
\hline "...we can practice every time" & & \\
\hline & "...expand our imagination in writing" & $\begin{array}{l}\text { "...in this way I could improve } \\
\text { my writing" }\end{array}$ \\
\hline
\end{tabular}

Table 04 provides a transcript of the perceptions that students could obtain during the course with Digital Didactic Materials as tools for the improvement of Reading and Grammar. The quotations were extracted from the list codes-quotations from the Atlas ti 7.

\section{Discussion}

Results presented improvement in reading comprehension and grammar structure formation by clear means of their posttests results. The posttests indicated a substantial increase in most of students' performance after the treatment. The effects of Digital Didactic Material showed a substantial variance, meaning there were positive results in terms of comprehension and grammar conveyance since they are statistically significant, and there was no visible sign of loss of motivation. Instead, students were involved in the tasks on a constant expectation of teacher correction and goal-pursuing. In that account, an important finding directly connected to the grammar skill (Zarzycka-Piskorz, 2016), presented a 90\% in the overall grading; thus, the effectiveness of technology integration into the English class was proved. Such results corroborate the openness that students had for learning difficult content through a gamification system such as Kahoot! and reassures the outcomes obtained in the present study. Qualitative accounting of the students' responses regarding preferences and impressions indicates similarities within the results of classroom engagement for the use of Kahoot! in a study carried out by Wang (2015). Correspondingly, his students who used Kahoot! presented positive outcomes with a 90\% 
of agreement of engagement during the quiz lessons and $100 \%$ of entirely active participation during the sessions.

Moreover, learners could benefit from their own individual progress in an active environment of selfregulation and focus. Further research on the effect of Digital Didactic Material for specific issues is suggested, considering the context in which students previously acquired their written skills knowledge. The results showed that students were eager to try this material in order to learn.

Some limitations came out during this research. First of all, the participants' performance of this study was not compared with a control group, so a study including a control group could be executed to see if their performance on reading and grammar may achieve a remarkable difference. In addition, a study including more participants could give a more vivid view to analyze the students' acceptance of the Digital Didactic Material because one limitation of this study was that only 37 students were included. From the 37 participants, 20 of them did not have the same amount of hours attending the laboratory, since they belonged to a subsequent study group, but they also used the same Digital Didactic Material. It is a limitation because it would be useful to know what would had happened if all the participants had had the same amount of hours in the laboratory. Now, the results are good; however, with a future study, they could be better.

Several prior studies on the field of technology in the classroom have been conducted all over the world, but fewer in a country like Ecuador, since the reality in our country is not the same as in more tech-savvy countries like The United States or China. Hence, the importance of this study relies on this particular reality. Last but not least, a qualitative research to collect teachers' attitudes towards the use of the Digital Didactic Material can also be conducted to gather more data and detailed expressions of the participants. This will better answer the questions including their justifications regarding the attitudes towards reading and grammar teaching.

\section{Conclusion}

After analyzing the results and comparing them to the existing literature body in the use of Digital Didactic Material, it is asserted that having specifically-oriented tasks with the aid of technological tools is beneficial.

There is a preference noted for techno-aids. There were outcomes found to the hypotheses of knowing if there was a significant acceptance of the use of Digital Didactic Material as well as statistical improvement for reading and grammar structure. The analysis presented differences between pre and posttests. Students did not present an outstanding performance prior to the treatment, and although there was more than one online tool used throughout the conduction of this research, the results estimate that learning performance augmented considerably at the posttest phase. Regarding students' opinions about the use of the mentioned tools, there is evidence that Quizlet was the most effective, followed by Storybird. It was found that students would use these out of class. Appropriate learning motivation encourages students to behave actively to excel in class and get engaged with what they are seeing in class; Thus, having appealing new material is necessary (Oktaviana, 2011). Lauermann and Barbossa (2018) seemingly verified that the controlled use of technology classroom practice enhances learning through better fluency, interaction and participation of students, due to leveraging students' motivation and engagement. Their findings were altogether positive regarding reading and writing practices by means of digital games and multimodal resources which make learners take individual action for their own progress and further academic success.

The contribution that the present study provides aims to give a clearer insight on the vast field of alternatives for language teaching and learning from an updated perspective of strategies that can be 
adapted intuitively in various educational scenarios. It isn't only technology as a means of academic betterment, but also as an upgraded and practical system of instruction.

\section{References}

Akdemir, Ö., Kunt, K., \& Tekin, I. (2012). The Effects of Interactive Exercises on Students' Achievement: Using the Open Source Authoring Application. Procedia - Social and Behavioral Sciences, 55, 1009-1013. https://doi:10.1016/j.sbspro.2012.09.591

Almirón, M.E., \& Porro, S. (2014). Las TIC en la enseñanza: un análisis de casos [ICT in education: a case analysis]. Revista Electrónica de Investigación Educativa, 16(2), 152-160.

Althaqafi, A. S. (2018). A Critical Review of Grammar Teaching Methodologies in the Saudi Context. English Language Teaching, 11(11), 65-73. https://doi:10.5539/elt.v11n11p65

Ausín, V., Abella, V., Delgado, V., \& Hortigüela, D. (2016). Aprendizaje Basado en Proyectos a través de las TIC: Una Experiencia de Innovación Docente desde las Aulas Universitarias [Project-based learning through ICT: An experience of teaching innovation from the university classrooms]. Formación Universitaria, 9(3), 31-38. https://doi:10.4067/s0718-50062016000300005

Bataineh, R., \& Mayyas, M. (2017). The utility of blended learning in EFL reading and grammar: A case for moodle. Teaching English with Technology, 17(3), 35-49.

Bravo, A., Ramírez, P., Faúndez, A., \& Astudillo, F. (2016). Propuesta Didáctica Constructivista para la Adquisición de Aprendizajes Significativos de Conceptos en Física de Fluidos [Didactic constructivist proposal for the acquisition of significant learning of concepts in fluid physics]. Formación Universitaria, 9(2), 105-114

Cabrera, P., Castillo, L., González, P., Quiñónez, A., \& Ochoa, C. (2018). The Impact of Using Pixton for Teaching Grammar and Vocabulary in the EFL Ecuadorian Context. Teaching English with Technology, 18(1), 53-76.

Chávez, D., \& Caicedo, A. (2014). TIC y argumentación: Análisis de tareas propuestas por docentes universitarios [ICT and argumentation: Analysis of tasks proposed by university teachers]. Estudios Pedagógicos, 40(2), 83-100.

Council of Europe. (2001). Common European framework of reference for languages: Learning, teaching, assessment. Cambridge. Cambridge University Press.

Courts, B., \& Tucker, J. (2012). Using Technology To Create A Dynamic Classroom Experience. Journal of College Teaching \& Learning (TLC), 9(2), 121-128. https://doi.org/10.19030/tlc.v9i2.6907

Creswell, J. (2014). Research Design Qualitative, Quantitative, And Mixed Method Approaches. SAGE Publications, Inc. 
Crujeiras, B., \& Jiménez, M. (2015). Desafíos planteados por las actividades abiertas de indagación en el laboratorio: articulación de conocimientos teóricos y prácticos en las prácticas científicas [Challenges posed by open research activities in the laboratory: articulation of theoretical and practical knowledge in scientific practices]. Enseñanza de las ciencias: revista de investigación y experiencias didácticas, 33(1), 63-84.

Dangel, H., \& Wang, C. (2008). Student Response Systems in Higher Education: Moving Beyond Linear Teaching and Surface Learning. Journal of Educational Technology Development and Exchange, 1(1), 93104. https://doi.org/10.18785/jetde.0101.08

Ellis, R. (2017). Position paper: Moving task-based language teaching forward. Language Teaching, 50(04), 507-526. doi:10.1017/s0261444817000179

Faul, F., Erdfelder, E., Lang, A.-G., \& Buchner, A. (2007). G*Power 3: A flexible statistical power analysis program for the social, behavioral, and biomedical sciences. Behavior Research Methods, 39(2), 175-191. https://doi: 10.3758/BF03193146

Faúndez, C. A., Rojas, Y. G., Pinto, A. A., \& Astudillo, H. F. (2015). Taller de Física Cuántica: un Método para Introducir Conceptos Fundamentales en una Actividad Extracurricular [Quantum physics workshop: a method for introducing fundamental concepts in an extracurricular activity]. Formación universitaria, 8(2), 53-62. https://dx.doi.org/10.4067/S0718-50062015000200008

Field, A. (2019). Discovering Statistics Using IBM SPSS statistics. SAGE Publications.

Fiad, S. B., \& Galarza, O. D. (2015). El Laboratorio Virtual como Estrategia para el Proceso de EnseñanzaAprendizaje del Concepto de Mol [The Virtual Laboratory as Strategy for the Teaching-Learning Process of the Concept of Mol]. Formación Universitaria, 8(4), 03-14. https://doi:10.4067/s071850062015000400002

Gilmanova, A., Nikitina, S., \& Khasanova, N. (2016). Using authentic literature to teach reading at EFL classes. International Journal of Humanities and Cultural Studies, 6(2), 355-362.

Hernández, R., Fernández, C., \& Baptista, P. (2010). Metodología de la investigación [Investigaction Methodology]. Mc-Graw Hill.

Hsu, C. K., Hwang, G. J., \& Chang, C. K. (2013). A personalized recommendation-based mobile learning approach to improving the reading performance of EFL students. Computers and Education, 63, 327336. https://doi: 10.1016/j.compedu.2012.12.004

Johnson, G. M. (2015). The Invention of Reading and the Evolution of Text. Journal of Literacy and Technology. Journal of Literacy and Technology Journal of Literacy and Technology, 16(1), 107-128.

Larsen-Freeman, D. (2015). Research into practice: Grammar learning and teaching. Language Teaching, 48(02), 263-280. https://doi:10.1017/s0261444814000408

Lauermann, V., \& Barbosa, D. (2018). Digital Technologies Applied to Textual Reading and Understanding in English: A Practical Approach Using Kahoot. Springer International Publishing. https://doi.org/10.1007/978-3-319-95522-3_7 
Muñoz-Justicia, J., \& Sahagún-Padilla, M. (2017). Hacer análisis cualitativo con Atlas.ti 7: Manual de uso [Do qualitative analysis with Atlas.ti 7: User manual]. Zenodo. http://doi.org/10.5281/zenodo.273997

Oktaviana, M. (2011). The Influence of the Use of Hydrocarbon Card Media Packages Against Motivation and Chemistry Learning Outcomes of Class X Semester Even High School Students in Bantul Yogyakarta Academic Year 2012/2013. Essay. Yogyakarta. UIN - SUNAN KALIJAGA

Organization for Economic Co-operation and Development. (2013). OECD skills outlook 2013: First results from survey of adult skills. OECD Publishing.

Ortega-Vergara, J. D., \& Medina-Payarez, I. J. (2015). Modelo Blended Learning para el desarrollo de competencias lectoras y escritoras: un desafío de aprendizaje en educación básica primaria en la Institución Educativa San Roque, Colombia [Blended Learning Model for the development of reading and writing skills: a learning challenge in primary basic education at the San Roque Educational Institution, Colombia]. Memorias, 13(23), 93-106. http://doi: http://dx.doi.org/10.16925/me.v13i23.1071

Polat, M. (2017). Teachers' Attitudes towards Teaching English Grammar: A Scale Development Study. International Journal of Instruction, 10(4), 379-398. http://doi: 10.12973/iji.2017.10422a

Ruiz, P. (2013). Nuevas tecnologías y estudiantes chilenos de secundaria: Aportes a la discusión sobre la existencia de nuevos aprendices [New technologies and Chilean high school students: Contributions to the discussion about the existence of new apprentices]. Estudios pedagógicos (Valdivia), 39(2), 279-298. https://dx.doi.org/10.4067/S0718-07052013000200018

Sawilowsky, S. (2009). New Effect Size Rules of Thumb. Journal of Modern Applied Statistical Methods, 8(2), 596-599. https://doi: 10.22237/jmasm/1257035100

Slavin, R. E., Lake, C., Chambers, B., Cheung, A., \& Davis, S. (2009). Effective reading programs for the elementary grades: a best-evidence synthesis. Review of Educational Research, 79, 1391-1465. https://doi: 10.3102/0034654309341374.

Stowell, J. R., \& Nelson, J. M. (2007). Benefits of electronic audience response systems on student participation, learning, and emotion. Teaching of Psychology, 34(4), 253-258. https://doi: 10.1080/00986280701700391

Turkmen, Y. \& Ayden, S. (2016). The Effects of Using Online Concordances on Teaching Grammar. Journal of the Institute of Social Sciences, 20(1), 145-152.

Wang, A. I. (2015). The wear out effect of a game-based student response system. Computers \& Education, 82, 217-227. https://doi:10.1016/j.compedu.2014.11.004

Zarzycka-Piskorz, E. (2016). Kahoot it or not? Can games be motivating in Learning Grammar? Teaching English with Technology, 16(3), 17-36. 